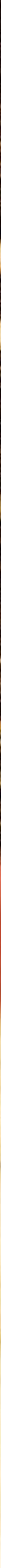

Editor I Letlhokwa George Mpedi 


\section{5 \\ Opinion Re: Use of Santa Paws in the Western Cape}

\section{Wim Alberts}

\section{Dear Santa}

I refer to our recent consultation.

I confirm the factual situation that an entity is conducting business at the Waterfront in Cape Town, delivering gifts using the name Santa Claus. Furthermore, customers at the shop are welcomed by a Santalike figure shouting "Ho Ho Ho". The entity also sells plastic figures with your likeness, bearing the name Santa Claus. They have a branch in Stellenbosch delivering playthings to pets under the name Santa Paws. They have another branch in George delivering toys to birds under the name Santa Claws.

Your legal position is as follows.

\section{Use of Santa Claus}

I discuss below the various relevant remedies.

(a) Passing off

In Jennifer Williams \& Associates \& Another $v$ Life Line Southern Transvaal 1996 (3) SA 408 (A) at 418 D - G the court has defined passing-off as:

"A species of wrongful competition in trade or business. In its classic form it usually consists in A representing, either expressly or impliedly (but almost invariably by the latter means), that the 
goods or services marketed by him emanate in the course of business from $B$ or that there is an association between such goods or services and the business conducted by $\mathrm{B}$. Such conduct is treated by the law as being wrongful because it results, or is calculated to result, in the improper filching of another's trade and/or in an improper infringement of his goodwill and/or in causing injury to that other's trade reputation. Such a representation may be made impliedly by $A$ adopting a trade name or get-up or mark for his goods which so resembles B's name or get-up or mark as to lead the public to be confused or to be deceived into thinking that A's goods or services emanate from $B$ or that there is the association between them referred to above."

In practice, it is accepted that underlying the action of the plaintiff is proof of the existence of a reputation in the relevant jurisdiction. In this case, it is the position about the Western Cape High court. You are of course, because of your long and extensive use of the title Santa Claus, famous in South Africa, and thus also in the Cape. Concerning confusion, one can merely note that the same mark is used about the same activity. We thus conclude that passing off would be a viable remedy to protect your rights. Because of your extensive reputation in both the name and appearance, our conclusion would also apply to the sale of Santa Claus figures.

(b) Section 34(1)(a) of the Trade Marks Act

This provision reads as follows:

"The rights acquired by registration of a trade mark shall be infringed by-

(a) the unauthorized use in the course of trade in relation to goods or services in respect of which the trade mark is registered, of an identical mark or of a mark so nearly resembling it as to be likely to deceive or cause confusion;"

We note from our records that your mark was registered in 1916, so the registration is more than 100 years old. The specifications are 
"Transport services in relation to the delivery of toys". Incidentally, this is a rather narrow description and I would suggest that we file for transport services as such. This would give you wider protection. In the current context, the marks are the same and the activity is the same. We are thus certain that you will be able to rely on this ground.

Also of a likewise application is section 35(3) of the Trade Marks Act which reads as follows:

"(3) The proprietor of a trade mark which is entitled to protection under the Paris Convention as a well-known trade mark is entitled to restrain the use in the Republic of a trade mark which constitutes, or the essential part of which constitutes, a reproduction, imitation or translation of the well-known trade mark in relation to goods or services which are identical or similar to the goods or services in respect of which the trade mark is well known and where the use is likely to cause deception or confusion."

(c) Section 34(1)(b) of the Trade Marks Act

This provision reads as follows:

"The rights acquired by registration of a trade mark shall be infringed by-

(b) the unauthorized use of a mark which is identical or similar to the trade mark registered, in the course of trade in relation to goods or services which are so similar to the goods or services in respect of which the trade mark is registered, that in such use there exists the likelihood of deception or confusion;"

The question in this regard is whether the retail services of the other side are similar to your registration. In the leading case of British Sugar Plc $v$ James Robertson \& Sons Ltd [1996] RPC 281 the following factors were mentioned:

\footnotetext{
- particular consumers

- particular products

- trade channels
} 
- found on same supermarket shelves?

- $\quad$ are products in competition?

In our estimation, the retail services are similar. We would, however, suggest that you file applications for retail services as well as for toys.

(d) Section 34(1)(c) of the Trade Marks Act

This provision reads as follows:

"The rights acquired by registration of a trade mark shall be infringed by-

(c) the unauthorized use in the course of trade in relation to any goods or services of a mark which is identical or similar to a trade mark registered, if such trade mark is well known in the Republic and the use of the said mark would be likely to take unfair advantage of, or be detrimental to, the distinctive character or the repute of the registered trade mark, notwithstanding the absence of confusion or deception..."

As mentioned above, we consider your mark to be well-known. Therefore, you will qualify for protection in terms of the above provision, as it relates to any goods or services. This implies that both the delivery service in Cape Town and the retail of Santa Claus figures can be enjoined.

\section{Use of Santa Paws/Santa Claws}

It was said in Laugh It Off Promotions CC $v$ South African Breweries International (Finance) BV t/a Sabmark International [2005] ZACC 7 par 78 that:

"Parody is appropriation and imitation, but of a kind involving a deliberate dislocation. Above all, parody presumes the authority and currency of the object work or form. It keeps the image of the original in the eye of the beholder and relies on the ability of the audience to recognise, with whatever degree of precision, the parodied work or text, and to interpret or 'decode' the allusion; in this sense the audience shares in a variety of ways the creation 
of the parody with the parodist. Unlike the plagiarist whose intention is to deceive, the parodist relies on the audience's awareness of the target work or genre; in turn, the complicity of the audience is a sine qua non of its enjoyment.

As Gredley and Maniatis write:

"The effect on the audience of parodic dislocation is often comic,
provoking laughter, not necessarily at the expense of the
parodied work or its author, but at the dislocation itself. Other
reactions can include shock, disgust, anger or even simply
intellectual pleasure at the recognition of the object work and at
the skill and imagination of the parodist... [It may be suggested]
that the courts are prepared to tolerate genuine parody,
especially in cases where the sole or primary injury to the
copyright owner is to his amour propre."

The tenor of the judgment is to protect humorous expressions. For this reason, I believe we would not be able to prevent the use of the captioned names.

\section{Use of $\mathrm{H}_{\sigma} \mathrm{H}_{\sigma} \mathrm{H}_{\sigma}$}

The only manner in which the above can be protected is to file a trade mark application for it. The following definition is pertinent then:

"'mark" means any sign capable of being represented graphically,
including a device, name, signature, word, letter, numeral, shape,
configuration, pattern, ornamentation, colour or container for
goods or any combination of the aforementioned;"

The part emphasised is problematic. Protection is arguably available in terms of the common law for the words Ho Ho Ho. However, I would suggest that we file a trade mark application to protect it. We shall lodge a musical annotation for the sound. 


\section{Attack on your registration}

I set out below the definition of "trade mark" in section 1 of the Act:

"'trade mark", other than a certification trade mark or a collective
trade mark, means a mark used or proposed to be used by a
person in relation to goods or services for the purpose of
distinguishing the goods or services in relation to which the mark
is used or proposed to be used from the same kind of goods or
services connected in the course of trade with any other person"

The part emphasized can, arguably, be problematic for you as you do not conduct trade, as per the concept of trade mark. However, the common law courts have protected the names of churches, welfare organisations, schools, political parties, and not-for-profit entities. Seemingly, the idea is to protect their goodwill in a broad sense. The Registrar is likely to follow the guidance of the courts. Everything considered, thus, I feel we would be able to overcome such an attack.

\section{Conclusion}

In conclusion, I am confident that we would prevail in any litigation. The other side has been trading for about eight months, building on your name. In principle, you could thus claim damages. However, an alternative might be to require them to donate gifts to the Red Cross' Children Hospital.

I look forward to hearing from you regarding the launch of proceedings, following the sending of a letter of demand.

RW ALBERTS

UJ Law Clinic 